Original Paper http://ajol.info/index.php/ijbcs http://indexmedicus.afro.who.int

\title{
Effect of chia seeds (Salvia hispanica) on postprandial glycaemia, body weight and hematological parameters in rats fed a high fat and fructose diet
}

\author{
Fabian Dominicus MIHAFU ${ }^{1,3^{*}}$, Beatrice Nyanchama KIAGE ${ }^{1}$, \\ Andrew Nyerere KIMANG' ${ }^{2}{ }^{2}$ and Judith Kanensi OKOTH ${ }^{1}$ \\ ${ }^{1}$ Department of Human Nutrition Sciences, School of Food and Nutrition Sciences, Jomo Kenyatta University \\ of Agriculture and Technology, P. O. Box 62000-00200, Nairobi, Kenya. \\ ${ }^{2}$ Department of Medical Microbiology, College of Health Sciences, Jomo Kenyatta University of Agriculture \\ and Technology, P. O. Box 62000-00200, Nairobi, Kenya. \\ ${ }^{3}$ Department of Applied Sciences, Mbeya University of Science and Technology, P.O. Box 131, Mbeya, \\ Tanzania. \\ * Corresponding author; E-mail: fmihafu21@gmail.com; Phone: +254 796233804/ +255 765426643
}

\section{ACKNOWLEDGEMENTS}

This work was supported by the DAAD/RUFORUM research grant. "In-Region Scholarship Programme", 2016 (57299300).

\begin{abstract}
Chia seeds (Salvia hispanica) are currently consumed by varied populations as superfoods due to their protective, functional and antioxidant properties. The aim of this study was to determine the effect of ground chia seeds/extracts on postprandial glycaemia, body weight, hematological parameters and cellular morphology in rats. Twenty male Wistar rats were assigned into three experimental groups and a control $(n=5)$. Each experimental group received $10 \mathrm{~g} / 20 \mathrm{~g}$ fructose/lard. Additionally, $90 \mathrm{~g}$ rat pellet was fed to group 1 and 3 which was supplemented with $20 \mathrm{~g}$ chia seed extract, group 2 received ground chia seeds only. Control group received $90 \mathrm{~g}$ rat pellet only for 28 days. The results on body weight changes indicated a gradual increase in body weight of chia seeds/extract fed rats as compared to fructose/lard group. There was an increase in postprandial blood glucose levels in group 1 from week I to IV contrary to groups supplemented with chia seeds/extract. Complete blood counts showed a significant increase $(\mathrm{p}=0.008)$ in mean corpuscular hemoglobin concentration, basophils $(\mathrm{p}=0.035)$, platelets $(\mathrm{p}=0.025)$ and red cell distribution width $(\mathrm{p}=0.008)$ in experimental groups compared to control. These results pinpoint the benefits of chia seeds.
\end{abstract}

(c) 2020 International Formulae Group. All rights reserved.

Keywords: Blood composition, functional food, glucose concentration, metabolic diseases, omega-3 fatty acids

\section{INTRODUCTION}

Excessive consumption of high-fat diets and foods that are calorie-dense, highly processed and quickly absorbable can lead to systemic inflammation and a cluster of cardiometabolic disorders, including obesity, hypertension, dyslipidaemia, glucose intolerance and insulin resistance (Alissa and Ferns, 2014). These increase the risks of chronic diseases such diabetes and 
cardiovascular diseases. There is growing interest in identifying novel therapeutic approaches including functional foods towards preventing and controlling chronic diseases and other health risks (Creus et al., 2016). Typical functional food contains bioactive compounds including dietary fiber, polyunsaturated fatty acids, phytochemicals and antioxidants that have potential roles in reducing the risk of chronic diseases (Gazem and Chandrashekariah, 2016). Chia seed is among the growing functional food that have been reported to protect the cardiovascular system, exhibit anti-inflammatory properties, anti-oxidative properties and control blood sugar and lipid metabolism (Gazem and Chandrashekariah, 2016; Marcinek and Krejpcio, 2017; Asgary et al., 2018).

Postprandial glycaemia (PPG) refers to blood glucose concentrations after a meal (Bernardo et al., 2015). It is a useful predictor of diabetes and cardiovascular events and its regulation is key to controlling metabolic diseases (Blaak et al., 2012). Normally, in nondiabetic conditions, plasma glucose concentrations rise approximately 30 to 60 minutes after a meal, rarely exceed $140 \mathrm{mg} / \mathrm{dL}$ and returning to preprandial levels 2 to 3 hours after. The extent and time of rise of plasma glucose concentration depends on a number of factors such as meal timing, quantity and composition. Furthermore, the rate of gastric emptying affects the absorption rate of meal components and is related to the postprandial blood glucose level after meals (Marathe et al., 2013). The PPG profile is determined by carbohydrate absorption, secretion of hormones (insulin and glucagon) and their corresponding effects on glucose metabolism in the liver and peripheral tissues (Marathe et al., 2013; Bernado et al., 2015).

Reactive oxygen species (ROS) can stimulate PPG which in turn aggravates inflammation and endothelial dysfunction and other complications associated with hyperglycemia (Arawwawala et al., 2009; Nwaoguikpe, 2010; Blaak et al., 2012; Bernardo et al., 2015). There is growing evidence that whole grains may play a central role in the prevention of chronic diseases (Vuksan et al., 2007). Epidemiological studies suggest a strong association between increased consumption of whole-grain foods and reduced risk of diabetes and cardiovascular disease (Ho et al., 2013; Alissa and Ferns, 2014; Asgary et al., 2018).

Chia seeds are currently consumed by varied populations due to their protective, functional and antioxidant properties attributed to the presence of dietary fibre, lipids, protein, phenolic compounds, minerals and omega-3 fatty acids, $\alpha$-linolenic acid (Gazem and Chandrashekariah, 2016; de Falcao, 2017; Prathyusha, 2019;). A study by Ho and colleagues (2013) demonstrated that both ground and whole chia seeds (Salba) equally attenuated blood glucose levels in a dosedependent manner when incorporated into bread and tested in healthy volunteers. Costantini et al. (2019) reported a significant decrease in endothelin-1 (ET-1) a biomarker of cardiometabolic diseases when spontaneously hypertensive rats were supplemented with chia seeds. Further, Vuksan et al. (2010) reported a reduced postprandial glycemia in individuals fed with bread containing up to $24 \mathrm{~g}$ chia seeds per day. Therefore, a therapeutic approach to treat diabetes is to decrease postprandial hyperglycemia.

Hematological parameters have been associated with health indices and are of great significance in routine clinical evaluation of the state of health (Etim et al., 2014; Kensa and Neelamegam, 2014). Therefore, examining blood composition can offer significant information for the diagnosis and prognosis of diseases in animals (Budzianowski et al., 2017). This is because the destruction mediated by free radicals results in the disruption of membrane fluidity, lipid peroxidation, protein denaturation and alteration of platelet functions that heighten chronic health problems such as diabetes, inflammation, atherosclerosis and cancer (Kensa and Neelamegam, 2014). Hence, variations in hematological parameters are regularly used to determine various statuses 
of the body as well as stress due to pathological, nutritional and environmental factors (Yakubu et al., 2017).

Chia seeds are rich in omega 3 fatty acids that play a key role in preventing the formation of clots and plaques in the arteries and so help to prevent cardiovascular diseases (Ullah et al., 2016; Prathyusha, 2019;).The present study was therefore aimed at determining the effects of ground chia seeds and its extracts on postprandial glycaemia, body weight changes, hematological parameters and cellular morphology in male Wistar rats.

\section{MATERIALS AND METHODS}

\section{Sample collection and preparation Collection and preparation of chia seeds}

Chia seeds were purchased from farmers in Molo, Nakuru County, Among'ura and Ongariama-Teso, Busia County all in Kenya. Other Chia black seeds and white seeds were purchased from Dr. Chia, the Kenyan company pioneering the seed's commercialization in East Africa based in Nairobi. This company outsources its seeds from Bukembo and Kigumba regions of Uganda. The seeds were cleaned by removing all the impurities and damaged seeds. Thereafter, they were crushed (Moulinex grinder, AR11, China) and the flour packed in sealed khaki bags (Paper bags Ltd, Kenya) and stored in a cool dry place until use.

\section{Preparation of chia seed oil extract}

About $200 \mathrm{~g}$ of ground chia seeds were mixed with $1000 \mathrm{ml}$ of $100 \%$ ethanol (Sharlau), and extracted using a shaker (Kika Labortechnik, KS 250 basic, Germany) overnight (12 hours) at room temperature. The mixture was then sieved with a sieve cloth to get the liquid portion. The liquid portion was then filtered with a filter paper number 1 in order to get a clear filtrate. The filtrate was then concentrated in a Rotary Evaporator RE 100 (Bibby sterilin Ltd, UK). The crude ethanolic extract of chia seeds was then dried in an air oven at $50{ }^{\circ} \mathrm{C}$ for 1 hour and later cooled in a desiccator. The extract was kept at $4{ }^{\circ} \mathrm{C}$ in the fridge (Hisense, RD-28DR4SA, China) until use.

\section{Preparation of lard and fructose}

The lard was prepared by rendering pork fat in Food Science Laboratory (meat and dairy processing workshop), Jomo Kenyatta University of Agriculture and Technology (JKUAT). Fructose (Fructofin C, Danisco Sweeteners Oy, Finland) was prepared by dissolving $20 \mathrm{~g}$ of fructose granules in $100 \mathrm{ml}$ distilled water $(\mathrm{w} / \mathrm{v})$.

\section{Animal experiment Experimental animals}

Male Wistar albino rats aged 8 to 10 weeks and weighing between $140 \mathrm{~g}$ to $250 \mathrm{~g}$ were used. The breeds were obtained from Small Animal Facility for Research and Innovation (SAFARI), College of Health Science, JKUAT. The rats were acclimatized on rat pellet (Unga farm Care (EA) Ltd, Nairobi) for two weeks before commencement of the experiment. The lard ( $4 \mathrm{~g} / \mathrm{rat})$, fructose ( $2 \mathrm{~g} / \mathrm{rat}$ ) and chia seed extracts ( $4 \mathrm{~g} / \mathrm{rat})$ were orally administered by a gavage for a period of 28 consecutive days. The animals were housed in plastic cages; water was given ad libitum during the experiment.

\section{Experimental design}

Twenty (20) Wistar albino rats were randomly assigned into three experimental groups and a control $(\mathrm{n}=5)$. Control group received $90 \mathrm{~g}$ of rat pellets (mice pencil) only, group 1 received $10 \mathrm{~g} / 20 \mathrm{~g}$ fructose/lard and 90 $\mathrm{g}$ rat pellets, group 2 received $10 \mathrm{~g} / 20 \mathrm{~g}$ fructose/lard supplemented with $90 \mathrm{~g}$ ground chia seeds and group 3 received $10 \mathrm{~g} / 20 \mathrm{~g}$ fructose/lard and $90 \mathrm{~g}$ rat pellets supplemented with $20 \mathrm{~g}$ chia seed extract. All these diets were given for 28 days. The composition of experimental diets and the control were shown in Table 1.

\section{Sample size}

Sample size was calculated based on 'Group comparison-one-way ANOVA' using degree of freedom (DF) as previously reported by Charan and Kantharia (2013) \& Arifin and 
Zahiruddin (2017). $\mathrm{n}=\mathrm{DF} / \mathrm{k}+1 ; \mathrm{N}=\mathrm{n} \times \mathrm{k}$; where $\mathrm{n}=$ number animals per group, $\mathrm{k}=$ number of groups, $\mathrm{N}=$ total number of animals. The power analysis approach (ANOVA) is between 10 to 20, so any sample that keeps DF (E) between 10 and 20 is considered adequate. The total number of animals obtained for this experiment was 20 .

\section{Blood collection}

At the beginning of the experiment the blood was collected by making a small cut on a tip of a tail, the tail was slowly milked to release blood on a strip inserted in glucometer (Accu-Check Active, Roche, Mannheim, Germany), the blood sugar levels were read and recorded. Postprandial glycemia was determined 2 hours after feeding on weekly basis while fasting blood glucose was determined at the end of the experiment using hand hold glucometer. At the end of the intervention, rats were anaesthetized with carbondioxide and blood collected from them by cardiac puncture. About $4 \mathrm{ml}$ of blood was collected into EDTA-anticoagulated tubes (BD, Belliver Industrial Estate, Plymouth, UK) from each animal and used for determining the parameters of interest.

\section{Hematological assays}

The hematological analysis was conducted at the Institute of Primate Research (IPR) Laboratory, Nairobi, Kenya. Whole blood with anticoagulant was analyzed for hematological parameters using Hematology Analyzer (Ac.T 5diff CP, Beckman Coulter, France). Parameters determined were red blood cells (RBC) count, blood hemoglobin concentration $(\mathrm{Hb})$, packed cell volume $(\mathrm{PCV})$, mean corpuscular volume (MCV), mean corpuscular hemoglobin (MCH), mean corpuscular hemoglobin concentration (MCHC), red cell distribution width (RDW), total leukocyte count (TLC), Neutrophils (NEUT), lymphocytes (LYM), monocytes (MON), eosinophils (EOS), basophils (BAS), platelets (PLT) and mean platelet volume (MPV).

\section{Clinical and diagnostic information}

These included appetite, body condition, hair coat, respiration and behavior. These were recorded on daily basis.

\section{Food intake, feces collection and weight records}

Food consumption was recorded daily. Feces from each cage were collected daily and at the end of the experiment lipids were extracted from them. The body weight of each rat was recorded daily until the end of the experiment. Body weight results were expressed as mean \pm standard deviation.

\section{Extraction of lipids from feces}

A modified Bligh and Dyer (1959) method was used. Dried feces were crushed using mortar and pestle, $2.5 \mathrm{~g}$ of crushed feces were weighed (W1) and placed in centrifuge tubes, $30 \mathrm{ml}$ of hexane was added and the tubes were placed on shaker for 2 hours, then vortexed for 5 minutes and filtered using Whatman paper number 1 . The filtrate was placed in preweighed flasks (W2) and evaporated to dryness on rotary evaporator. The concentrate was dried in an oven at $70{ }^{\circ} \mathrm{C}$ for 30 minutes, cooled in desiccator and weighed (W3). The percentage lipids was calculated as;

$\%$ Lipids $=\frac{\mathrm{W} 3-\mathrm{W} 2}{\mathrm{~W} 1} \times 100$

\section{Statistical analysis}

Stata Corp 14.0 was used in data analysis. Primary data were analyzed and presented as the mean $+/$ - standard deviation (SD). To determine the level of significance, the data were further analyzed using one-way analysis of variance (ANOVA). The difference in the test values versus the control values was proven to be statistically significant at $\mathrm{p} \leq 0.05$.

\section{Ethical approval}

All aspects of animal care and experimentation were performed according to the Guide for Care and Use of Laboratory Animals of the National Institutes of Health. The study was approved by the JKUAT Institutional Ethics Review Committee (IERC). 
Table 1: Nutrient composition of the diets.

\begin{tabular}{lccc}
\hline Nutrient & $\begin{array}{c}\text { Control (Mice } \\
\text { pencil) } \mathbf{( \% )}\end{array}$ & $\begin{array}{c}\text { Experimental diet } \\
\text { (ground chia seed) } \mathbf{( \% )}\end{array}$ & $\begin{array}{c}\text { Experimental diet (chia } \\
\text { seed extract) }(\boldsymbol{\%})\end{array}$ \\
\hline Crude protein & 18.1 & 20.1 & 4 \\
Crude fat & 8 & 30.9 & 26.0 \\
Crude fiber & 7 & 25.6 & 18.0 \\
Carbohydrates & - & 14.1 & 12.0 \\
a-linolenic & - & 51.0 & 57.0 \\
Linoleic & - & 18.0 & 18.3 \\
\hline
\end{tabular}

\section{RESULTS}

\section{Effect of chia seeds/extract on body weight changes in rats}

Results on body weight changes in relation to the initial assessment were compared between the control and experimental groups. There was a significant increase $(\mathrm{p}=0.001)$ in body weight changes between week I and IV for the group 1 that was fed with fructose/lard and rat pellet only. There was a gradual increase in body weight of the rats fed with chia seeds/extract, however the difference between groups was not significant $(\mathrm{p}=1.000)($ Table 2).

\section{Effect of ground chia seeds and its extract on postprandial glycaemia}

Postprandial glycaemia (PPG) in group 3 reduced significantly as compared to other groups for 60,90 and 120 minutes in week I (Table 3). In week II there was no significant difference in blood glucose levels between groups. In week III, there was an increase in PPG for group 1 and the difference was significant $(\mathrm{p}=0.0001)$ for $30,60,90$ and 120 minutes. Likewise, in week IV, group 1 differed significantly $(p=0.0001)$ from other groups as PPG increased for 30, 60, 90 and 120 minutes. On the other hand, fasting blood glucose ranged from $4.94 \pm 0.35-6.42 \pm 0.36$, $3.84 \pm 0.50-9.26 \pm 0.88,3.76 \pm 0.47-5.54 \pm$ 0.49 and $4.12 \pm 0.24-5.08 \pm 0.38$ for a control, group 1,2 and 3 respectively.

\section{Effect of ground chia seeds and its extract on hematological parameters and cellular morphology \\ Results on complete blood counts} showed no significant difference $(\mathrm{p}=1.000)$ in red blood cells (RBC) count, blood hemoglobin concentration $(\mathrm{Hb})$, packed cell volume $(\mathrm{PCV})$, mean corpuscular volume (MCV), mean corpuscular hemoglobin $(\mathrm{MCH})$, total leukocyte count (TLC), Neutrophils (NEUT), lymphocytes (LYM), monocytes (MON), eosinophils (EOS) and mean platelet volume (MPV) between experimental groups and a control (Table 4). There was a significant increase $(p=0.008)$ in mean corpuscular hemoglobin concentration (MCHC), basophils (BAS) $(\mathrm{p}=0.035)$, platelets (PLT) $(\mathrm{p}=0.025)$ and red cell distribution width (RDW) ( $\mathrm{p}=0.008)$ in experimental groups as compared to control (Table 4). Mean platelet volume (MPV) increased significantly $(\mathrm{p}=0.04)$ in a control group unlike experimental groups.

Blood smears indicated morphological changes of cells. Most cells observed to be creanated and some indicated leptocytosis (Figures $1 \& 2$ ).

\section{Extracted lipids from feces}

Results on lipids (\%) extracted from feces indicated high levels of lipids in chia seed extract fed rats $(2.92 \pm 0.27)$, followed by ground chia fed rats $(1.90 \pm 0.70)$ as compared to the control $(1.77 \pm 0.23)$. The amount of lipids in chia seed extract fed rats differed significantly $(p=0.004)$ from the group that was fed with fructose/lard and rat pellets only. 
Table 2: Body weight changes of Wistar rats fed with fructose/lard and ground chia seeds/extract.

\begin{tabular}{lcccc}
\hline Week & Control & Group 1 & Group 2 & Group 3 \\
\hline I & $186.73 \pm 8.94^{\mathrm{a}}$ & $229.02 \pm 13.77^{\mathrm{b}}$ & $197.59 \pm 28.91^{\mathrm{a}}$ & $189.21 \pm 51.71^{\mathrm{a}}$ \\
I & $190.02 \pm 12.79^{\mathrm{a}}$ & $266.24 \pm 16.75^{\mathrm{ab}}$ & $211.12 \pm 31.98^{\mathrm{a}}$ & $206.78 \pm 69.65^{\mathrm{a}}$ \\
& $195.49 \pm 7.06^{\mathrm{a}}$ & $281.27 \pm 15.72^{\mathrm{ab}}$ & $217.98 \pm 34.36^{\mathrm{a}}$ & $216.98 \pm 80.20^{\mathrm{a}}$ \\
III & $214.34 \pm 3.98^{\mathrm{a}}$ & $300.78 \pm 18.44^{\mathrm{a}}$ & $219.19 \pm 37.23^{\mathrm{a}}$ & $223.23 \pm 89.55^{\mathrm{a}}$ \\
IV & $27.61 \pm 4.96$ & $71.76 \pm 4.67$ & $21.6 \pm 8.32$ & $34.02 \pm 37.84$ \\
Body weight change & &
\end{tabular}

Values are means \pm SD (standard deviation) $(n=5)$; means with the same superscript within the same column are not significantly different $(\mathrm{p}<0.05$ ). Control (received $90 \mathrm{~g}$ rat pellet only); Group 1 (received $10 \mathrm{~g} / 20 \mathrm{~g}$ fructose/lard and $90 \mathrm{~g}$ rat pellet); Group 2 (received $10 \mathrm{~g} / 20 \mathrm{~g}$ fructose/lard supplemented with $90 \mathrm{~g}$ ground chia seeds); Group 3 (received $10 \mathrm{~g} / 20 \mathrm{~g}$ fructose/lard, $90 \mathrm{~g}$ rat pellet supplemented with $20 \mathrm{~g}$ chia seed extract).

Table 3: Postprandial glycaemia of the rats fed with fructose/lard and ground chia seeds/extract.

\begin{tabular}{|c|c|c|c|c|c|}
\hline \multirow{2}{*}{$\begin{array}{l}\text { Period } \\
\text { (Week) }\end{array}$} & \multirow{2}{*}{$\begin{array}{l}\text { Time } \\
\text { (min) }\end{array}$} & \multicolumn{3}{|c|}{ Postprandial glycaemia $(\mathrm{mmol} / \mathrm{L})$} & \multirow[b]{2}{*}{ Group 3} \\
\hline & & Control & Group 1 & Group 2 & \\
\hline \multirow{4}{*}{ I } & 30 & $6.02 \pm 0.48^{\mathrm{a}}$ & $6.22 \pm 0.48^{\mathrm{a}}$ & $6.20 \pm 0.48^{\mathrm{a}}$ & $5.34 \pm 0.56^{\mathrm{a}}$ \\
\hline & 60 & $5.76 \pm 0.64^{\mathrm{ab}}$ & $6.06 \pm 0.37^{\mathrm{ab}}$ & $6.22 \pm 0.59^{\mathrm{a}}$ & $5.08 \pm 0.53^{b}$ \\
\hline & 90 & $5.62 \pm 0.55^{\mathrm{ab}}$ & $6.28 \pm 0.86^{\mathrm{a}}$ & $5.88 \pm 0.60^{\mathrm{ab}}$ & $4.84 \pm 0.77^{b}$ \\
\hline & 120 & $5.42 \pm 0.39^{b}$ & $6.32 \pm 0.65^{\mathrm{a}}$ & $5.12 \pm 0.68^{\mathrm{b}}$ & $4.44 \pm 0.56^{b}$ \\
\hline \multirow{4}{*}{ II } & 30 & $7.20 \pm 0.86^{\mathrm{a}}$ & $7.14 \pm 0.88^{a}$ & $6.22 \pm 0.22^{\mathrm{a}}$ & $6.32 \pm 0.94^{\mathrm{a}}$ \\
\hline & 60 & $6.14 \pm 0.51^{\mathrm{a}}$ & $6.98 \pm 1.14^{\mathrm{a}}$ & $6.32 \pm 0.60^{\mathrm{a}}$ & $5.82 \pm 0.73^{\mathrm{a}}$ \\
\hline & 90 & $6.16 \pm 0.41^{\mathrm{a}}$ & $7.42 \pm 1.35^{\mathrm{a}}$ & $6.28 \pm 0.38^{\mathrm{a}}$ & $6.06 \pm 1.46^{\mathrm{a}}$ \\
\hline & 120 & $6.10 \pm 0.84^{\mathrm{a}}$ & $7.06 \pm 1.41^{\mathrm{a}}$ & $5.82 \pm 0.63^{\mathrm{a}}$ & $5.40 \pm 0.10^{\mathrm{a}}$ \\
\hline \multirow{4}{*}{ III } & 30 & $6.04 \pm 0.22^{b}$ & $8.08 \pm 0.45^{\mathrm{a}}$ & $5.88 \pm 0.56^{\mathrm{b}}$ & $5.42 \pm 0.56^{\mathrm{b}}$ \\
\hline & 60 & $5.72 \pm 0.33^{\mathrm{b}}$ & $8.60 \pm 0.94^{\mathrm{a}}$ & $5.28 \pm 0.52^{\mathrm{b}}$ & $5.84 \pm 0.44^{\mathrm{b}}$ \\
\hline & 90 & $5.22 \pm 0.47^{\mathrm{b}}$ & $8.56 \pm 0.97^{\mathrm{a}}$ & $6.16 \pm 0.38^{b}$ & $5.94 \pm 0.50^{\mathrm{b}}$ \\
\hline & 120 & $5.26 \pm 0.32^{\mathrm{b}}$ & $8.40 \pm 0.81^{\mathrm{a}}$ & $5.80 \pm 0.87^{\mathrm{b}}$ & $5.90 \pm 0.40^{\mathrm{b}}$ \\
\hline \multirow{4}{*}{ IV } & 30 & $6.22 \pm 0.30^{\mathrm{b}}$ & $9.50 \pm 0.45^{\mathrm{a}}$ & $6.56 \pm 0.55^{b}$ & $6.48 \pm 1.15^{\mathrm{b}}$ \\
\hline & 60 & $5.20 \pm 0.25^{\mathrm{b}}$ & $9.54 \pm 0.70^{\mathrm{a}}$ & $5.92 \pm 0.39^{\mathrm{b}}$ & $6.08 \pm 1.26^{\mathrm{b}}$ \\
\hline & 90 & $5.70 \pm 0.29^{b}$ & $9.82 \pm 0.46^{\mathrm{a}}$ & $5.16 \pm 0.57^{b}$ & $5.54 \pm 1.07^{\mathrm{b}}$ \\
\hline & 120 & $5.26 \pm 0.28^{\mathrm{b}}$ & $9.30 \pm 0.79^{a}$ & $4.86 \pm 0.04^{\mathrm{b}}$ & $5.34 \pm 1.22^{\mathrm{b}}$ \\
\hline
\end{tabular}

Values are means $\pm \mathrm{SD}(\mathrm{n}=5)$. Means with the same superscript within the same row are not significantly different $(\mathrm{p}<0.05)$. Control (received $90 \mathrm{~g}$ rat pellet only); Group 1 (received $10 \mathrm{~g} / 20 \mathrm{~g}$ fructose/lard and $90 \mathrm{~g}$ rat pellet); Group 2 (received 10 $\mathrm{g} / 20 \mathrm{~g}$ fructose/lard supplemented with $90 \mathrm{~g}$ ground chia seeds; Group 3 (received $10 \mathrm{~g} / 20 \mathrm{~g}$ fructose/lard, $90 \mathrm{~g}$ rat pellet supplemented with $20 \mathrm{~g}$ chia seed extract). 
Table 4: Hematological parameters of rats fed with fructose/lard and ground chia seeds/ extract.

\begin{tabular}{|c|c|c|c|c|}
\hline Parameter & Control & Group 1 & Group 2 & Group 3 \\
\hline $\mathrm{RBC}\left(10^{6} / \mu \mathrm{L}\right)$ & $7.85 \pm 0.49^{\mathrm{a}}$ & $7.81 \pm 0.21^{\mathrm{a}}$ & $8.14 \pm 0.40^{\mathrm{a}}$ & $7.93 \pm 0.37^{\mathrm{a}}$ \\
\hline $\mathrm{Hb}(\mathrm{g} / \mathrm{dL})$ & $14.16 \pm 0.60^{\mathrm{a}}$ & $13.66 \pm 0.63^{\mathrm{a}}$ & $14.74 \pm 1.38^{a}$ & $14.24 \pm 0.24^{\mathrm{a}}$ \\
\hline PCV (\%) & $45.60 \pm 2.10^{\mathrm{a}}$ & $43.74 \pm 2.58^{\mathrm{a}}$ & $46.64 \pm 3.95^{\mathrm{a}}$ & $44.50 \pm 0.52^{\mathrm{a}}$ \\
\hline $\operatorname{MCV}(\mathrm{ft})$ & $58.20 \pm 1.64^{\mathrm{a}}$ & $56.00 \pm 2.45^{\mathrm{a}}$ & $57.20 \pm 3.83^{\mathrm{a}}$ & $56.60 \pm 1.14^{\mathrm{a}}$ \\
\hline $\mathrm{MCHC}(\%)$ & $31.04 \pm 0.27^{\mathrm{b}}$ & $31.34 \pm 0.53^{b}$ & $31.58 \pm 0.44^{\mathrm{b}}$ & $32.80 \pm 0.25^{\mathrm{a}}$ \\
\hline $\mathrm{MCH}(\mathrm{pg})$ & $18.06 \pm 0.53^{\mathrm{a}}$ & $17.52 \pm 0.56^{\mathrm{a}}$ & $18.08 \pm 1.13^{\mathrm{a}}$ & $18.18 \pm 0.28^{\mathrm{a}}$ \\
\hline RDW (\%) & $12.64 \pm 0.34^{\mathrm{ab}}$ & $13.42 \pm 0.69^{\mathrm{a}}$ & $11.94 \pm 0.86^{\mathrm{b}}$ & $11.96 \pm 0.34^{\mathrm{b}}$ \\
\hline $\operatorname{TLC}\left(\times 10^{3} / \mu \mathrm{L}\right)$ & $9.54 \pm 2.47^{\mathrm{a}}$ & $10.34 \pm 5.63^{\mathrm{a}}$ & $11.64 \pm 1.76^{\mathrm{a}}$ & $9.40 \pm 0.66^{\mathrm{a}}$ \\
\hline NEUT (\%) & $1.97 \pm 0.32^{\mathrm{a}}$ & $3.25 \pm 3.16^{\mathrm{a}}$ & $2.424 \pm 0.85^{\mathrm{a}}$ & $1.63 \pm 0.05^{\mathrm{a}}$ \\
\hline LYM (\%) & $7.42 \pm 2.38^{\mathrm{a}}$ & $5.87 \pm 1.54^{\mathrm{a}}$ & $8.12 \pm 0.86^{\mathrm{a}}$ & $6.45 \pm 0.42^{\mathrm{a}}$ \\
\hline $\operatorname{MON}(\%)$ & $0.67 \pm 0.24^{\mathrm{a}}$ & $1.048 \pm 1.03^{\mathrm{a}}$ & $0.87 \pm 0.40^{\mathrm{a}}$ & $0.48 \pm 0.02^{\mathrm{a}}$ \\
\hline EOS $(\%)$ & $0.07 \pm 0.02^{\mathrm{a}}$ & $0.08 \pm 0.04^{\mathrm{a}}$ & $0.09 \pm 0.02^{\mathrm{a}}$ & $0.08 \pm 0.01^{\mathrm{a}}$ \\
\hline BAS (\%) & $0.1 \pm 0.05^{\mathrm{ab}}$ & $0.08 \pm 0.06^{\mathrm{b}}$ & $0.12 \pm 0.04^{\mathrm{ab}}$ & $0.18 \pm 0.02^{\mathrm{a}}$ \\
\hline $\operatorname{PLT}\left(\times 10^{3} / \mu \mathrm{L}\right)$ & $543.2 \pm 72.40^{\mathrm{a}}$ & $521.8 \pm 99.71^{\mathrm{a}}$ & $711.4 \pm 156.36^{\mathrm{a}}$ & $679.8 \pm 61.21^{\mathrm{a}}$ \\
\hline MPV & $7.86 \pm 0.52^{\mathrm{a}}$ & $6.94 \pm 0.67^{b}$ & $6.96 \pm 0.32^{\mathrm{b}}$ & $6.72 \pm 0.24^{b}$ \\
\hline
\end{tabular}

Values are means \pm SD $(\mathrm{n}=5)$. Means with the same superscripts within the same row are not significantly different $(\mathrm{p}<0.05)$. Control (received $90 \mathrm{~g}$ rat pellet only); Group 1 (received $10 \mathrm{~g} / 20 \mathrm{~g}$ fructose/lard and $90 \mathrm{~g}$ rat pellet); Group 2 (received 10 $\mathrm{g} / 20 \mathrm{~g}$ fructose/lard supplemented with $90 \mathrm{~g}$ ground chia seeds; Group 3 (received $10 \mathrm{~g} / 20 \mathrm{~g}$ fructose/lard, $90 \mathrm{~g}$ rat pellet supplemented with $20 \mathrm{~g}$ chia seed extract). Red blood cells (RBC) count, blood hemoglobin concentration (Hb), packed cell volume (PCV), mean corpuscular volume (MCV), mean corpuscular hemoglobin (MCH), mean corpuscular hemoglobin concentration (MCHC), red cell distribution width (RDW), total leukocyte count (TLC), Neutrophils (NEUT), lymphocytes (LYM), monocytes (MON), eosinophils (EOS), basophils (BAS), platelets (PLT) and mean platelet volume (MPV).

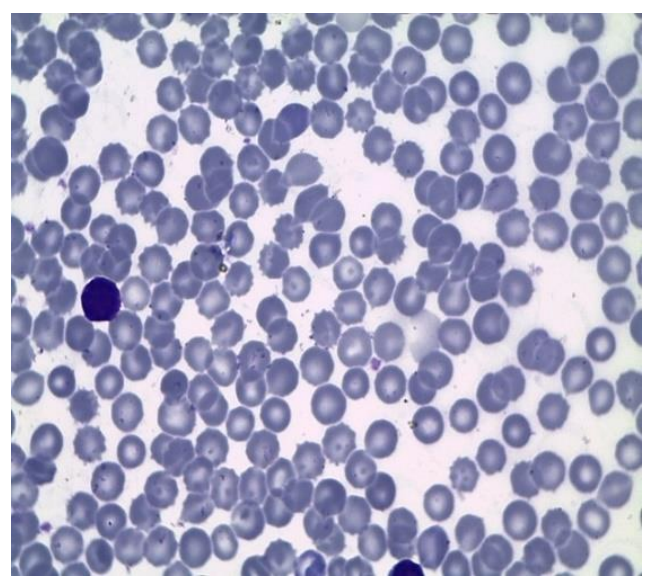

Figure 1: Leptocytosis.

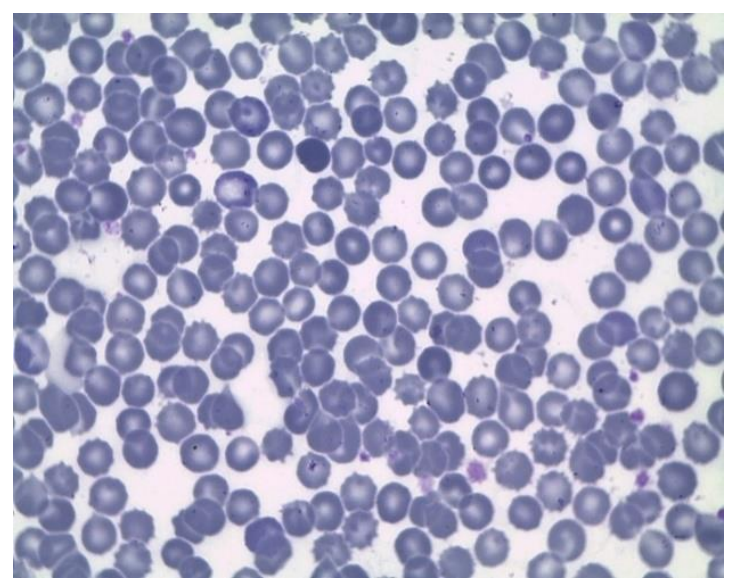

Figure 2: Creanated cells. 


\section{DISCUSSION}

Chia seeds have a great nutritional potential due to their composition. They are widely consumed for various health benefits such as maintaining healthy serum lipid and glucose levels and cardioprotective effects (Ali et al., 2012; Ullah et al., 2016). PPG is a useful predictor of diabetes and cardiovascular events and its regulation is key to controlling metabolic diseases (Bernardo et al., 2015). Foods containing high fats and sugars impose high risk of diabetes and cardiovascular disease. Low intake of saturated fatty acids with increased intake of omega-3 polyunsaturated fatty acids can lessen food related health risks (Nourmohammdi et al., 2014).

Chia seeds have been reported by several studies (Gazem and Chandrashekariah, 2016; Ullah et al., 2016) to be useful in controlling blood glucose levels and offering cardioprotective effects because they contain high levels of omega 3 fatty acids. Overweight and obesity are modifiable risk factors of some of these metabolic diseases like type 2 diabetes (Nourmohammdi et al., 2014). Our study showed a decrease in weight gain in experimental groups supplemented with ground chia seeds and its extracts (Table 2). This indicates that chia seeds can be a good candidate for weight loss if executed with other therapeutic life changes such as reducing intake of foods and food products rich in saturated fats and trans-fatty acids; increasing intake of foods high in omega- 3 fatty acids and dietary fiber including fruits and vegetables, reducing intake of sodium to less than 2400 milligrams per day and reducing physical inactivity (Whitney and Rolfes, 2018; Toscano et al., 2015).

There was an increase in blood glucose levels in group 1 from week I to week IV contrary to group 2 and 3 . Our study showed a significant decrease in PPG in experimental groups that included chia seeds and its extract (Table 3). Indeed, it has been reported that controlling PPG independently activates homeostasis of thrombotic-prone conditions, mediated by brief overproduction of reactive oxygen species (Zheng et al., 2010; Blaak et al., 2012). These may stimulate inflammation, hypercoagulability and endothelial dysfunction that favors vasoconstriction and hypertension, causing metabolic diseases (type 2 diabetes and cardiovascular disease) (Kensa and Neelamegam, 2014). Lower PPG is presumed to reduce ROS that may damage proteins, lipids and DNA hence upsurge resistance in insulin sensitive tissues especially under the absence of adequate antioxidants (Jenkins et al., 2006). Therefore, decreased PPG in groups supplemented with ground chia seeds/extracts are promising for primary prevention of type 2 diabetes and cardiovascular diseases. Hence, the economic cost of diabetes could be reduced through the control of postprandial glycaemia.

High red cell distribution width (RDW) is an indication of nutrient deficiency particularly iron, folate and vitamin $\mathrm{B}_{12}$, can also show macrocytic anemia (Agiang et al, 2017). In the study, the experimental group that was supplemented with fructose/lard had a significant increase $(\mathrm{p}<0.008)$ in RDW compared to the groups that were supplemented with ground chia seeds/extract only. This can be an indication that chia seeds may boost micronutrients in body and especially iron (Amato et al, 2015). However, in our study, we noted that PCV in experimental group 1 was low compared to group 2 that was supplemented with ground chia seeds; this may be an indication of cell destruction, since low packed cell volume indicates cellular damage.

The decline observed in the platelet counts in group 2 highlight possible effects on blood clotting when fructose/lard are supplemented to normal rat pellet. Platelet count is one of the essential screen tests of platelet function (Monteomo et al., 2018). An increase in $\mathrm{RBC}$ count led to the corresponding increase in $\mathrm{Hb}$ and $\mathrm{PCV}$ in groups supplemented with chia seeds/oil extract compared to the control. However, erythrocyte indices, $\mathrm{MCH}$ and $\mathrm{MCHC}$ were increased in experimental groups 1 and 2 compared to a control. These parameters are used to measure the size and weight per unit volume of red blood cells. The size of the cells may be normal (normocytic), below normal (microcytic) and above normal (macrocytic). This is comparable to what is experienced in iron deficiency anemia (Agiang et al, 2017). 
In this study $\mathrm{MCV}$ and $\mathrm{MCH}$ were lower in fructose/lard supplemented group compared to those of ground chia seed/ extract fed group, this indicates microcytic anemia, a condition in which red blood cells become too small than normal and usually characterized by a low MCV. Iron deficiency is the most common cause of microcytic anemia. The rats might have developed this condition because this group was only fed fructose, lard and rat pellets in which iron content was not guaranteed. Our study also showed an increase in the concentration of TLCs in group supplemented with ground chia seeds (Table 4). This implies that chia seeds are capable of boosting the immune system (Monteomo et al., 2018). Generally, low levels of hematological parameters were observed in group 1 as compared to the groups supplemented with ground chia seeds/extract (Table 4).

On the other hand, cellular morphology indicated crenation and leptocytosis, these were much observed in a control group and group 1 that was fed with fructose/lard and rat pellets only. Crenation implies formation of abnormal notched surfaces on cells as result of water loss through osmosis (Figure 1). In absence of gastrointestinal bleeding, uremia or any other medical conditions, crenation may indicate aged cells or may occur in vitro when blood stays for a prolonged period of time in the collection tubes. In this study, the blood was kept at $4{ }^{\circ} \mathrm{C}$ for 24 hours before analysis, it might be one of the reason for crenation. Leptocytosis is a condition in which red blood cells become thinner than normal and may contain less hemoglobin (Figure 2). It is a feature of iron deficiency anemia, thalassemia and liver disease (Youngson, 2005).

Increased level of lipids in feces from ground chia seeds/extract fed rats may be an indication that, they are capable of inhibiting pancreatic lipase an enzyme responsible for digestion of dietary fat. There is possibility of slowing down the digestion of fats after consumption of chia seeds/extract hence their release through feces. Inhibition of this enzyme is thought to improve dyslipidemia. Pancreatic lipase inhibitors are considered valuable therapeutic agent for treating diet-induced obesity (Aruna et al., 2014).

\section{Conclusion}

In conclusion, findings in this study provide the evidence that chia seeds can be the good candidate for lowering postprandial glycaemia and improving hematological parameters which are marked as good indicators of the physiological status of animals. Results on body weight changes reveal the significance of chia seeds in controlling weight gain. Not only that but also the seeds can be used to slow down the digestion of fats by inhibiting pancreatic lipase. It is therefore believed that, the next generation of functional foods, supplements and processed foods will have the chia seeds as their primary ingredient.

\section{COMPETING INTERESTS}

The authors declare that they have no competing interests.

\section{AUTHORS' CONTRIBUTIONS}

FDM conceived the experiment, performed the experiments, analyzed the data, interpreted the data and wrote the paper; BNK provided an advice on experimental design, read and corrected the paper; ANK provided an advice on experimental design and animal handling; JKO read and corrected the paper.

\section{ACKNOWLEDGEMENTS}

We are grateful to Mary Karwitha Kimathi, Perminus Kimanthi Njururi and Mark Mogaka Nyandege for animal handling and care.

\section{REFERENCES}

Agiang MA, Dongo BS, Williams IO, UtuBaku AB. 2017. Assessment of the haematological indices of albino rats fed diets supplemented with jackfruit bulb, seed or a blend of bulb and seed. Int. J. Biol. Chem. Sci., 11(1): 397-407. DOI: http://dx.doi.org/10.4314/ijbcs.v11i1.31

Alissa EM, Ferns GA. 2014. Potential cardioprotective effects of functional Food. In Functional Foods and Dietary Supplements: Processing Effects and Health Benefits ( $1^{\text {st }}$ edn). John Wiley \& Sons, Ltd; 463-487.

Amato M, Caruso MC, Guzzo F, Galgano F, Commisso M, Bochicchio R, Labella R, 
Favati F. 2015.Nutritional quality of seeds and leaf metabolites of Chia (Salvia hispanica L.) from Southern Italy. Eur. Food Res. Technol., 241: 615-625. DOI: http://dx.doi.org/10.1007/s00217-0152488-9

Arawwawala M, Thabrew I, Arambewela L. 2009. Antidiabetic activity of Trichosanthes cucumerina in normal and streptozotocin-induced diabetic rats. Int. J. Biol. Chem. Sci., 3(2): 287-296. http://ajol.info/index.php/ijbcs

Arifin WN, Zahiruddin WM. 2017. Sample size calculation in animal studies using resource equation approach. Malays $J$ Med Sci., 24(5):101-105. DOI https://doi.org/10.21315/mjms2017.24.5. 11

Aruna A, Vijayalakshmi K, Karthikeyan V. 2014. Pancreatic lipase inhibitory screening of Citrullus lanatus leaves. The Pharma Innovation Journal, 3(7): 44-52

Asgary S, Rastqar A, Keshvari M. 2018. Functional Food and Cardiovascular Disease Prevention and Treatment: A Review. J Am Coll Nutr., 1-27. DOI: 10.1080/07315724.2017.1410867

Bernardo MA, Silva ML, Santos E, Moncada MM, Brito J, Proença L, Singh J, deMesquita MF. 2015. Effect of Cinnamon Tea on Postprandial Glucose Concentration. Journal of Diabetes Research., 1-6. DOI: http://dx.doi.org/10.1155/2015/913651

Blaak EE, Antoine JM, Benton D, Björck I, Bozzetto L, Brouns F. 2012. Impact of postprandial glycaemia on health and prevention of disease. Obesity reviews., 13: 923-984. DOI: $10.1111 /$ j.1467789X.2012.01011.x

Bligh EG, Dyer WJ. 1959. A rapid method of total lipid extraction and purification. Can. J. Biochem. Physiol., 37(8): 911-7. DOI: http://dx.doi.org/10.1139/o59-099

Budzianowski J, Pieszko K, Burchardt P, Rzeźniczak J, Hiczkiewicz J. 2017.The Role of Hematological Indices in Patients with Acute Coronary Syndrome. Disease Markers, 1-9. DOI: https://doi.org/10.1155/2017/3041565

Charan J, Kantharia N. 2013. How to calculate sample size in animal studies? Journal of Pharmacology

and
Pharmacotherapeutics, 4(4): 303-306. DOI: $\quad$ https://doi.org/10.4103/0976500X.119726

Creus M, Ferreira MR, Oliva ME, Lombardo YB. 2016. Mechanisms Involved in the Improvement of Lipotoxicity and Impaired Lipid Metabolism by Dietary $\alpha$ Linolenic Acid Rich Salvia hispanica L (Salba) Seed in the Heart of Dyslipemic Insulin-Resistant Rats. J Clin Med., 5(2): 18. DOI: $10.3390 / \mathrm{jcm} 5020018$

Costantini L, Molinari R, Merendino N. 2019. Effects of Chia Seed Supplementation on Biochemical Markers of Cardiometabolic Diseases in Spontaneously Hypertensive Rats. Acta Alimentaria., 48(4): 538-545. DOI: 10.1556/066.2019.0005

de Falco B, Amato M, Lanzotti V. 2017. Chia seeds products: an overview. Phytochem Rev., 16: 745-760. DOI: 10.1007/s11101017-9511-7

Etim NN, Williams ME, Akpabio U, Offiong EEA. 2014. Hematological Parameters and Factors Affecting Their Values. Agric Sci., 2(1): $\quad 37-47 . \quad$ DOI: 10.12735/as.v2i1p37

Gazem RAA, Chandrashekariah SA. 2016. Pharmacological Properties of Salvia hispanica (Chia) Seeds: a review. J Crit Rev., 3(3): 63-67.

Ho H, Lee AS, Jovanovski E, Jenkins AL, DeSouza R, Vuksan V. 2013. Effect of whole and ground Salba seeds (Salvia Hispanica $L$.) on postprandial glycemia in healthy volunteers: a randomized controlled, dose-response trial. Eur J Clin Nutr., $\quad$ 67: $786-788 . \quad$ DOI: 10.1038/ejcn.2013.103

Kensa VM, Neelamegam R. 2014. Evaluation of haematological properties of normal Albino rats exposed to ethanolic extract of Hydrilla verticillata (L.F.) Royle collected from unpolluted and polluted water sources. Int. J. Curr. Microbiol. App. Sci., $\quad 3(12): \quad 409-416$. http://www.ijcmas.com

Khan TA, Zafar F. 2005. Haematological Study in Response to Varying Doses of Estrogen in Broiler Chicken. Int. J. Poultry Sci., 4(10): 748-751. DOI: 10.3923/ijps.2005.748.751

Jenkins DJA, Kendall CWC, Josse AR, Salvatore S, Brighenti F, Augustin LSA, 
Ellis PR, Vidgen E, Rao AV. 2006. Almonds Decrease Postprandial Glycemia, Insulinemia and Oxidative Damage in Healthy Individuals. J. Nutr., 136: 2987-2992

Lavie CJ, Milani RV, Ventura HO. 2009. Obesity and Cardiovascular Disease. Risk Factor, Paradox, and Impact of Weight Loss. J Am Coll Cardiol., 53(21): 192532. DOI: $10.1016 /$ j.jacc.2008.12.068

Marathe CS, Rayner CK, Jones KL, Horowitz M. 2013. Relationships between gastric emptying, postprandial glycemia and incretin hormones. Diabetes Care., 36: 1396-1405. DOI: $10.2337 / \mathrm{dc} 12-1609$

Marcinek K, Krejpcio Z. 2017. Chia Seeds (Salvia hispanica): Health Promoting Properties and Therapeutic Applications - a review. Rocz Panstw Zakl Hig., 68(2): 123-129.

Monteomo GF, Kamagate A, Yapo AP. 2018. Effects of metabolic syndrome on blood cells to Wistar rats. J Diabetes Metab Disord Control., 5(6): 222-225. DOI: 10.15406/jdmdc.2018.05.00170

Nieman DC, Cayea EJ, Austin MD, Henson DA, McAnulty SR, Jin F. 2009. Chia seed does not promote weight loss or alter disease risk factors in overweight adults. Nutr Res., 29: 414-418. DOI: 10.1016/j.nutres.2009.05.011

Nourmohammdi M, Ejtahed H-S, Mirmiran P, Hekmatdoost A. 2014. Dietary fatty acid composition and metabolic syndrome: a review. JNSD., 1(1): 28-36. www.jnsd.tums.ac.ir

Nwaoguikpe RN. 2010. The effect of extract of bitter leaf (Vernonia amygdalina) on blood glucose levels of diabetic rats. Int. J. Biol. Chem. Sci., 4(3): 721-729. http://www.ajol.info/indx.php/ijbcs

Prathyusha P, Kumari BA, Suneetha WJ, Srujana MNS. 2019. Chia seeds for nutritional security. J Pharmacognosy and Phytochem., 8(3): 2702-2707. www.phytojournal.com

Toscano LT, Toscano LT, Tavares RL, da Silva CSO, Silva AS. 2015. Chia induces clinically discrete weight loss and improves lipid profile only in altered previous values. Nutr Hosp., 31(3): 11761182. DOI:10.3305/nh.2015.31.3.8242

Ullah R, Nadeem M, Khalique A, Imran M, Mehmood S, Javid A, Hussain J. 2016. Nutritional and therapeutic perspectives of Chia (Salvia hispanica L.): a review. $J$ Food Sci Technol., 53(4):1750-1758. DOI: 10.1007/s13197-015-1967-0

Vuksan V, Whitham D, Sievenpiper JL, Jenkins AL, Rogovik AL, Bazinet RP, Vidgen E, Hanna A. 2007. Supplementation of Conventional Therapy with the Novel Grain Salba (Salvia hispanica L.) Improves Major and Emerging Cardiovascular Risk Factors in Type 2 Diabetes. Diabetes care, 30(11): 2804-2810. DOI: $10.2337 / \mathrm{dc} 07-1144$

Vuksan V, Jenkins AL, Dias AG, Lee AS, Jovanovski E, Rogovik AL, Hanna A. 2010. Reduction in postprandial glucose excursion and prolongation of satiety: possible explanation of the long-term effects of whole grain Salba (Salvia hispanica L.). Eur J Clin Nutr., 64: 436438. DOI: 10.1038/ejen.2009.159

Whitney EN, Rolfes SR. 2018. Understanding Nutrition $\left(15^{\text {th }}\right.$ edn) Wadsworth, Cengage Learning, Belmont: California.

Yakubu OE, Olawale O, Arowora KA, Imo C. 2017. Biochemical Changes in Haematological and Liver Function Parameters in Intoxicated Male Albino Rats Treated with Hymenocardia acida Leaves Ethanolic Extract. Insights Biomed., 2(2): 1-5. DOI: 10.21767/25725610.100010

Youngson RM. 2005. Collins Dictionary of Medicine $\left(4^{\text {th }}\right.$ edn $)$. Harper Collins: Reno, NV, U.S.A

Zheng F, Lu W, Jia C, Li H, Wang Z, Jia W. 2010. Relationships between glucose excursion and the activation of oxidative stress in patients with newly diagnosed type 2 diabetes or impaired glucose regulation. Endocrine., 37(1): 201-208. DOI: $10.1007 / \mathrm{s} 12020-009-9296-6$ 